\title{
STRATEGI PENGEMBANGAN KEDISIPLINAN SISWA
}

\author{
Ahmad Manshur \\ IAI Sunan Giri Bojonegoro \\ ahmanshur@gmail.com
}

\begin{abstract}
Abstrak
Penelitian ini dilakukan dengan tujuan untuk medeskripsikan strategi pengembangan kedisiplinan siswa. Penelitian ini menggunakan metode deskriptif kualitatif. Subyek penelitian adalah siswa dan guru pada madrasah Tsanawiyah Bahrul Ulum Bulu Balen Bojonegoro. Pengumpulan data dilakukan dengan menggunakan metode observasi, wawancara, dan dokumentasi. Hasil dalam penelitian ini adalah:1. Strategi pengembangan kedisiplinan MTs Bahrul Ulum Bulu Balen Bojonegoro yaitu: a) Penyiapan visi, misi, motto, dan tujuan, b) Penyiapan program kegiatan khusus, program kegiatan ini sengaja disiapkan khusus untuk mensosialisasikandan membimbing dan mengawasi pelaksanaan pendidikan kedisiplinan. c) Tata tertib, ini digunakan sebagai aturan bertindak bagi siswa. d) Sosialisasi, yaitu sosialisasi tentang kedisiplinan, baik dalam tataran materi maupun aplikasinya. 2. pelaksanaan pendidikan kedisiplinan di MTs Bahrul Ulum Bulu Balen Bojonegoro sudah berjalan dengan sukses, baik dalam aplikasinya maupun hasilnya, ini terbukti dengan kedisiplinan siswa yang semakin meningkat, baik kedisiplinan dalam belajar maupun dalam bersikap/ bergaul dengan temantemannya.
\end{abstract}

\section{Kata Kunci: Setrategi pengembangan, kedisiplinan siswa}

\section{A. PENDAHULUAN}

Masalah pendidikan adalah merupakan masalah yang berhubungan langsung dengan hidup dan kehidupan manusia. Pendidikan merupakan usaha dari manusia dewasa yang telah sadar akan kemanusiaannya dalam membimbing, melatih, mengajar dan menanamkan nilai-nilai serta dasar-dasar pandangan hidup kepada generasi muda, agar nantinya menjadi manusia yang sadar dan bertanggungjawab akan tugas-tugas hidupnya 
sebagai manusia, sesuai dengan sifat hakekat dan ciri-ciri kemanusiaannya. ${ }^{1}$

Dengan demikian, pendidikan yang dijadikan salah satu alat untuk membentuk pribadi manusia sangatlah perlu dimasuki tentang pengetahuan kedisiplinan, karena kedisiplinan sangatlah perlu ditanamkan disetiap pribadi manusia. Manusia akan selalu bisa mengendalikan dan mengontrol apa yang akan dilaksanakannya hanya dengan melalui kehidupan yang teratur dan disiplin.

Hidup disiplin memang sangat perlu dilatih dan dibiasakan dalam kehidupan sehari-hari, karena dengan kebiasaan tersebut manusia akan benar- benar terlatih dan dapat merasakan hidup yang berarti, manusia juga akan selalu mendapatkan kepercayaan dari sesamanya dikarenakan rasa disiplin dan tanggungjawabnya yang tinggi.

Namun pentingnya peranan kedisiplinan dalam kehidupan manusia jarang diperhatikan, sehingga pendidikan dan aplikasi tentang disiplin sangat jarang sekali diterapkan didalam kehidupan sehari-hari. Kata-kata disiplin merupakan hal yang mudah diucapkan tetapi cukup sulit untuk diterapkan. Penerapan kedisiplinan baik dalam tataran pendidikan maupun aplikasinya dalam kehidupan sehari-hari harus di optimalkan sehingga masyarakat dalam mengisi era globalisasi ini mampu bersaing di lapangan secara sehat dan sportif.

Seperti yang dijelaskan di atas bahwa disiplin adalah sesuatu hal yang sangat penting dalam kehidupan manusia, oleh karena itu maka penulis terdorong untuk mengamati dan mengkaji lebih jauh tentang "Strategi pengembangan Kedisiplinan Siswa"

\footnotetext{
${ }^{1}$ Zuhairini dkk., Filsafat Pendidikan Islam, Bumi Aksara, Jakarta, 1989, hlm. 10
} 


\section{B. PEMBAHASAN}

\section{Pengertian Strategi}

Mc. Leod (1989) mengutarakan bahwa secara harfiah dalam bahasa Nana Sudjana (1988) mengatakan bahwa strategi mengajar adalah "taktik" yang digunakan guru dalam melaksanakan proses belajar mengajar (pengajaran) agar dapat mempengaruhi siswa (peserta didik) mencapai tujuan pengajaran (TIK) secara lebih efektif dan efesien. ${ }^{2}$

Strategi adalah sarana yang digunakan untuk mencapai tujuan akhir (sasaran). Tetapi strategi bukanlah sekedar sesuatu rencana. Strategi ialah rencana yang menyatukan: strategi mengikat semua bagian perusahaan menjadi satu. Strategi itu luas; strategi meliputi semua aspek penting perusahaan. Strategi itu terpadu: semua bagian dari rencana itu serasi satu sama lainnya dan bersesuaian. ${ }^{3}$

\section{Komponen-Komponen Strategi}

Komponen-komponen yang dimilki oleh suatu strategi, yakni:

a. Tujuan, khususnya dalam bidang pendidikan, baik dalam bentuk instructional effect (hasil yang segera dicapai) maupun nurturant effect (hasil jangka panjang)

b. Siswa atau peserta didik melakukan kegiatan belajar, terdiri dari peserta latihan yang sedang dipersiapkan untuk menjadi tenaga professional

c. Materi pelajaran, yang bersumber dari ilmu/bidang studi yang telah dirancang oleh GBPP dan sumber masyarakat

d. Logistik, sesuai dengan kebutuhan bidang pengajaran yang meliputi waktu, biaya, alat, kemapuan guru/pelatih dan sebagainya yang relevan

\footnotetext{
${ }^{2}$ Ahmad Rohani dan Drs. H. Abu Ahmadi, Pengelolaan Pengajaran, Rineka Cipta, Jakarta, hlm. 33

${ }^{3}$ William F. Glueck, Lawrence R. Jauch, Manajemen Strategis dan Kebijakan Perusahaan, Erlangga, Jakarta, hlm. 9
} 
dengan usaha pencapaian tujuan pendidikan. ${ }^{4}$

\section{Strategi Pengembangan Kedisiplinan}

Dalam pengembangan kedisiplinan dapat dilakukan langkahlangkah sebagai berikut:

a. Dengan Pembiasaan

Anak dibiasakan melakukan sesuatu dengan baik, tertib dan tertur, misalnya berpakaian rapi, keluar masuk kelas harus hormat guru, harus memberi salam dan lain sebagainya.

b. Dengan Contoh Dan Teladan

Dengan tauladan yang baik atau uswatun hasanah, karena murid akan mengikuti apa yang mereka lihat pada guru, jadi guru sebagai panutan murid untuk itu guru harus menjadi contoh yang baik

c. Dengan Penyadaran

Kewajiban bagi para guru untuk memberikan penjelasanpenjelasan, alasan-alasan yang masuk akal atau dapat diterima oleh anak. Sehingga dengan demikian timbul kesadaran anak tentang adanya perintah-perintah yang harus dikerjakan dan larangan-larangan yang harus ditinggalkan

d. Dengan Pengawasan Atau Kontrol

Bahwa kepatuhan anak atau tata tertib mengenal juga naik turun, dimana hal tersebut disebabkan oleh adanya situasi tertentu yang mempengaruhi terhadap anak. Adanya anak yang menyeleweng atau tidak mematuhi peraturan maka perlu adanya pengawasan atau kontrol yang itensif terhadap situasi yang tidak diinginkan akibat akan menginginkan keseluruhan. ${ }^{5}$

\footnotetext{
${ }^{4}$ Oemar Hamalik, Pengembangan Kurikulum dan Pembelajaran, Trigenda Karya, Jakarta,1994, hlm. 70-80

${ }^{5}$ Hafi Anshari, Pengantar Ilmu Pendidikan, Usaha Nasional, Surabaya, 1983,hlm 670.
} 
Adanya peranan disiplin dalam kehidupan sehari-hari memang sangat penting bagi perkembangan sumber daya manusia. Oleh karena itu penanaman disiplin harus benar-benar dilaksanakan dengan baik. Dalam penerapan dan penanaman disiplin harus disesuaikan dengan perkembangan jiwa peserta didik atau pelaku disiplin, karena kita harus menyadari kemampuan kognitifnya peserta didik atau pelaku disiplin.

\section{Pengertian Disiplin}

Disiplin berarti setiap macam pengaruh yang ditujukan untuk menolong anak mempelajari cara-cara menghadapi tuntutan yang datang dari lingkungannya dan juga cara-cara menyelesaikan tuntutan-tuntutan yang mungkin diajukan terhadap lingkungannya. ${ }^{6}$

Soegeng Priyodarminto, SH. dalam bukunya "Disiplin Kiat Menuju Sukses" disiplin didefinisikan sebagi suatu kondisi yang tercipta dan terbentuk melalui proses dari serangkaian perilaku yang menunjukkan nilai-nilai ketaatan, kepatuhan, keteraturan, dan atau ketertiban. $^{7}$

Disiplin adalah suatu perubahan tingkah laku yang teratur dalam menjalankan tugas-tugasnya atau pekerjaannya, yang tidak melanggar sebuah aturan yang telah disepakati bersama. Sikap disiplin itu muncul pada diri sendiri untuk berbuat sesuai dengan keinginan untuk mencapai sebuah tujuan. ${ }^{8}$

\footnotetext{
${ }^{6}$ Alex Sobur, Anak Masa Depan, Angkasa, Bandung, 1991, hlm. 144

${ }^{7}$ Soejitno Irmim, Abdul Rochim, Membangun Disiplin Diri Melalui Kecerdasan Spiritual dan Emosional, Batavia Press, Cet. I, 2004, hlm. 5

${ }^{8}$ Suryaningsih, Pengaruh Disiplin Terhadap Peningkatan Prestasi Hasil Belajar Siswa MTsN Malang I, RS. PI, 2004, hlm. 25
} 


\section{Tujuan Diadakannya Disiplin}

Menurut Charles Schaefer tujuan disiplin ada dua macam yaitu:

a. Tujuan jangka pendek adalah membuat anak-anak anda terlatih dan terkontrol, dengan mengajarkan mereka bentuk-bentuk tingkah laku yang pantas dan yang tidak pantas atau yang masih asing bagi mereka.

b. Tujuan jangka panjang, perkembangan pengendalian diri sendiri dan pengarahan diri sendiri (Self control and self direction) yaitu dalam hal mana anak dapat mengarahkan diri sendiri, tanpa pengaruh dan pengendalian dari luar. ${ }^{9}$

Tujuan dari keseluruhan dari disiplin adalah membentuk prilaku sedemikian rupa sehingga ia akan sesuai dengan peran-peran yang ditetapkan oleh kelompok budaya, tempat individu itu didefinisikan. ${ }^{10}$

\section{Fungsi Disiplin}

Disiplin merupakan pengendalian dan pengarahan segala perasaan dan tindakan seseorang yang ada dalam lembaga pendidikan untuk menciptakan dan memelihara suatu suasana bekerja efektif. Berdisiplin akan membuat seseorang memiliki kecakapan mengenai cara belajar yang baik, juga merupakan bentuk proses kearah pembentukan yang baik, yang akan menciptakan suatu pribadi yang luhur. ${ }^{11}$

Di lembaga pendidikan sangat penting sekali dengan adanya peraturan disiplin, karena dengan peraturan disiplin tersebut seluruh warga lembaga pendidikan akan bisa melaksanakan tugas dengan baik dan tepat waktu serta kehidupannya teratur.

\footnotetext{
${ }^{9}$ Chales Schaefer, Cara Efektif Mendidik dan Mendisiplinkan Anak, Jakarta, Kesaint Blanc, 1986, hlm.3

${ }^{10}$ Hurlock EB, Perkembangan Anak, Erlangga, Jakarta, 1993, hlm. 82

${ }^{11}$ The Liang Gie, Cara Belajar Yang Efisien, Pusat Kemajuan Studi UMG Press, Yogjakarta,1975, hlm. 51
} 


\section{Upaya Penanaman Disiplin}

Disiplin berarti adanya kesediaan untuk mematuhi peraturanperaturan dan larangan-larangan. Jadi setiap siswa yang mempunyai disiplin tinggi adalah mereka yang mentaati segala peraturan dan tata tertib dengan sadar tanpa adanya tuntutan dari pihak luar, baik ada yang mengawasi maupun tidak.

Langkah-langkah untuk menanamkan disiplin ialah:
a. Dengan pembiasaan
b. Dengan contoh dan Tauladan
c. Dengan penyadaran
d. Dengan Pengawasan

\section{PEMBAHASAN HASIL PENELITIAN}

Setelah dipaparkan hasil penelitian, maka penulis akan memberikan analisa sebagai berikut:

1. Strategi pengembangan kedisiplinan dalam meningkatkan kualitas pemebelajaran merupakan sebuah perwujudan dari visi, misi, motto dan tujuan pendidikan MTs Bahrul Ulum Bulu Balen Bojonegoro. Oleh karena itu untuk mewujudkan cita-cita yang tertuang dalam visi, misi, motto dan tujuan tersebut. MTs Bahrul Ulum Bulu Balen Bojonegoro memiliki beberapa strategi yang dijadikan kunci untuk mensukseskan pelaksanaan pengembangan kedisiplinan dalam meningakatkan kualitas pembelajaran

a. Visi, Misi, Motto dan Tujuan

Visi, misi, motto dan tujuan merupakan pondasi awal dari pelaksanaan pendidikan kedisplinan. Empat hal ini yang telah memberikanarah awal terhadap pelaksanaan pendidikan kedisiplinan di MTs Bahrul Ulum Bulu Balen Bojonegoro, dan juga sebagai tolak ukur keberhasilan pelaksanaan pengembangan 
kedisiplinan di MTs Bahrul Ulum Bulu Balen Bojonegoro

b. Program Kegiatan Khusus

Program kegiatan khusus yang diprogramkan dalam rangka menunjang pendidikan kedisiplinan MTs Bahrul Ulum Bulu Balen Bojonegoro diadakan program kegiatan khusus, yaitu Tadarus AlQur'an, latihan dasar kedisiplinan (LDK), latihan kader kepemimpinan (LKK), Pramuka, Razia, Pengadaan Buku Kasus dan pemberian tugas belajar aktif.

Beberapa program tersebut diprogramkan dalam rangka pengembangan pendidikan kedisiplinan yang telah diamanatkan didalam visi, misi, motto, dan tujuan MTs Bahrul Ulum Bulu Balen Bojonegoro, program kegiatan khusus ini yang dijadikan sebagai pemicu tumbuhnya disiplin siswa.

c. Tata Tertib

Dalam rangka pengembangan pendidikan kedisiplinan tata tertib ini digunakan sebagai petunjuk untuk acuan bagaimana seorang siswa harus berbuat yang sesuai dengan hak dan kewajiban yang ia miliki. Sehingga siswa tahu mana yang diharuskan dan mana yang dilarang. Tata tertib ini juga berfungsi sebagai peraturan tertulis yang mengikat dan siswa harus mematuhi dan melaksanakan dengan baik.

d. Sosialisi

Sosialisasi dilaksanakan oleh wali kelas dan guru pada jam pelajarannya di kelas, disini wali kelas memberikan arahan secara materi maupun pelaksanaan bagaimana harus hidup disiplin.

e. Pendekatan

Strategi pendekatan ini digunakan untuk mengidentivikasi gejala-gejala permasalahan yang timbul dari siswa. Pendekatan ini dilakukan melalui dua arah, yaitu pendekatan dengan orang tua 
sebagai bentuk kerjasama pembimbingan kepada siswa, dan pendekatan dengan siswa dalam rangka identivikasi permasalahan dari dekat secara langsung.

f. Sarana dan Prasarana

Karena disiplin memerlukan latihan dan pembiasaan, dalam rangka menerapkannya pendidikan kedisiplinan memang harus ditunjang sarana dan prasarana yang cukup mendukung, contohnya untuk melatih disiplin siswa dalam hal belajar, maka suasana belajar di madrasah harus menyenangkan, buku-buku pelajaran baik buku pokok maupun buku pendukung juga harus lengkap. Sehingga siswa termotivasi untuk selalu belajar karena bukubukunya menarik dan lengkap, begitu pula laboratorium juga dilengkapi.

g. Evaluasi

Strategi terakhir yang diprogramkan oleh MTs Bahrul Ulum Bulu Balen Bojonegoro adalah evaluasi, evaluasi ini merupakan sebuah kegiatan yang memberikan kontrol penilaian terhadap pelaksanaan pendidikan kedisiplinan. Evaluasi dilaksanakan rutin satu kali dalam satu minggu, evaluasi pertama ini berbentuk rapat dinas yang dipimpin oleh Kepala Madrasah, dan evaluasi yang kedua melalui jurnal kelas dan kartu point siswa. Evaluasi melalui jurnal kelas dan kartu point siswa dilakukan oleh wali kelas.

h. Pembiasaan

Pembiasaan merupakan faktor pendukung yang sangat penting dalam menegakkan kedisiplinan, dengan adanya pembiasaan untuk berdisiplin dan mematuhi aturan baik bagi Kepala Sekolah, guru, siswa dan karyawan yang telah ditetapkan maka harapan untuk menciptakan kehidupan yang harmonis dan teratur dapat dicapai dikarenakan tidak terjadi perbuatan-perbuatan yang 
mengarahpadatindakan indisipliner.

i. Adanya keteladanan para dewan guru dan karyawan.

Keteladanan merupakan hal yang pokok dalam keberhasilan dalam pegembangan kedisiplinan, mengingat anak- anak merupakan peniru ulung maka mereka perlu contoh dan figur yang perlu diteladani dalam kehidupan sehari-hari termasuk kehidupan di lingkungan sekolah. Keteladanan tersebut dapat berupa datang dan pulang tepat waktu, berseragam sesuai dengan ketentuan dan patuh pada peraturan yang telah ditetapkan dengan adanya keteladanan ini diharapkan akan dapat memotivasi siswa untuk berdisiplin.

2. Aplikasi strategi pengembangan kedisiplinan di MTs Bahrul Ulum Bulu Balen Bojonegoro Dalam Meningkatkan Kualitas Pembelajaran

Aplikasistrategi pengembangan kedisiplinan yangtelah dicanangkan oleh MTs Bahrul Ulum Bulu Balen Bojonegorotelah dilaksanakan dengan maksimal dan hasilnya cukup suskses. Hal ini dibuktikan bahwa siswa MTs Bahrul Ulum Bulu Balen Bojonegoro telah mengetahui apa yang disebut disiplin baik dari tataran materi (96 \% siswa) maupun pelaksanaannya (93 \% siswa). Sejak penerapan pendidikan kedisiplinan ini, siswa MTs Bahrul Ulum Bulu Balen Bojonegoro menunjukkan perubahan yang lebih baik dalam hal disiplin waktu, belajar maupun bergaul dengan sesamanya.

Dalam hal bergaul dengan teman-temannya $98 \%$ siswa MTs Bahrul Ulum Bulu Balen Bojonegoro menunjukkan sikap yang baik dan ramah. Padahal kalau dilihat dari fenomena yang ada pada umumnya seusia anak MTs masih sering bertengkar dan bentrok dengan temanya.

3. Sedangkan dalam hal belajar siswa MTs Bahrul Ulum Bulu Balen Bojonegoro

Bojonegoro menunjukkan peningkatan, karena $55 \%$ siswa tidak pernah bolos sekolah, dan mereka aktif mengikuti pelajaran 
dengan baik, dibuktikan dengan $72 \%$ selalu aktif dan ketika meninggalkannya selalu izin, kemudian dalam hal pekerjaan rumah (PR) $66 \%$ siswa MTs Bahrul Ulum Bulu Balen Bojonegoro selalu mengerjakan, sedangkan masalah belajar dirumah $72 \%$ siswa juga selalu mempelajari ulang pelajaran yang diajarkan di sekolah.

Kegemaran siswa dalam hal kegiatan ekstra kurikuler dalam rangka menambah wawasan keilmuan juga mengalami peningkatan walaupun masih dalam ukuran minimal, ini terlihat dari 23 \% siswa merupakan aktifis dari salah satu kegiatan ekstra kurikuler dan $44 \%$ siswa masih kadang-kadang. Kalau dilihat dari beberapa data diatas, proses aplikasi strategi pengembangan kedisiplinan untuk meningkatkan kualitas pembelajaran dapat dikatakan berhasil. Dan hal ini perlu ditingkatkan agar mendapatkan hasil yang maksimal.

\section{KESIMPULAN}

Dari penelitian yang telah dilaksanakan oleh peneliti dengan judul "Strategi Pengembangan Kedisiplinan", berdasarkan data yang telah di peroleh peneliti melalui dokumentasi, interview dan angket, maka dapat disimpulkan sebagai berikut:

1. Strategi pengembangan kedisiplinan yaitu:

Strategi merupakan langkah-langkah yang digunakan MTs Bahrul Ulum Bulu Balen Bojonegoro dalam mewujudkan pendidikan kedisiplinan. Strategi pengembangan kedisiplinan MTs Bahrul Ulum Bulu Balen Bojonegoro yaitu: Penyiapan visi, misi, motto, dan tujuan, Penyiapan program kegiatan khusus, Tata tertib, Sosialisasi, Pendekatan, Sarana dan Prasarana, Evaluasi, pembiasaan, dan keteladanan.

2. Aplikasi Strategi Pengembangan Kedisiplinan di MTs Bahrul Ulum Bulu Balen Bojonegoro. 
Setelah data dikumpulkan dapat disimpulkan bahwa pelaksanaan pendidikan kedisiplinan di MTs Bahrul Ulum Bulu Balen Bojonegoro sudah berjalan dengan sukses, baik dalam aplikasinya maupun hasilnya, ini terbukti dengan kedisiplinan siswa yang semakin meningkat, baik kedisiplinan dalam belajar maupun dalam bersikap/ bergaul dengan teman-temannya. Hal ini terbukti dengan jawaban angket siswa yang terdiri dari 12 item, mayoritas jawabannya: a) Siswa yang sadar untuk selalu hidup disiplin disemua tempat $93 \%$, b) Siswa yang tidak pernah bolos (tidak masuk tanpa izin) $55 \%$, c) Siswa yang tidak pernah meninggalkan jam pelajaran 72 $\%$, d) Siswa yang aktif mengikuti kegiatan ekstra kurikuler $23 \%$, e) Siswa yang selalu mengerjakan tugas pekerjaan rumah (PR) $66 \%$ f) Siswa yang mempelajari ulang pelajaran yang diajarkan di sekolah 72 $\%$, g) Pergaulan siswa dengan teman-temanya $98 \%$ baik dan ramah.

Keberhasilan MTs Bahrul Ulum Bulu Balen Bojonegoro dalam melaksanakan pengembangan kedisiplinan tersebut dikarenakan siswa yang memahami dan sadar tentang disiplin adalah 96\%, kemudian keberhasilan ini juga karena giatnya MTs Bahrul Ulum Bulu dalam melaksanakan sosialisai baik dalam tataran materi maupun aplikasinya, yaitu $98 \%$ siswa menegaskan hal tersebut.

Untuk masalah disiplin kedatangan masuk sekolah pada waktu pagi sudah baik, tetapi perlu ditingkatkan, karena siswa yang sering telambat sekolah masih $57 \%$. Hal ini perlu dicarikan solusi yang lebih lanjut. 


\section{DAFTAR PUSTAKA}

Ahmad Rohani dan Drs. H. Abu Ahmadi, Pengelolaan Pengajaran, Rineka Cipta, Jakarta, tt

Alex Sobur, Anak Masa Depan, Angkasa, Bandung, 1991

Chales Schaefer, Cara Efektif Mendidik dan Mendisiplinkan Anak, Jakarta, Kesaint Blanc, 1986

Hafi Anshari, Pengantar Ilmu Pendidikan, Usaha Nasional, Surabaya, 1983,hlm 670 .

Hurlock EB, Perkembangan Anak, Erlangga, Jakarta, 1993

Muhibbin Syah, M.Ed, Psikologi Pendidikan Dengan Pendekatan Baru, PT Remaja Rosda Karya, Bandung, 2003

Oemar Hamalik, Pengembangan Kurikulum dan Pembelajaran, Trigenda Karya, Jakarta,1994

Soejitno Irmim, Abdul Rochim, Membangun Disiplin Diri Melalui

Kecerdasan Spiritual dan Emosional, Batavia Press, Cet. I, 2004

Suryaningsih, Pengaruh Disiplin Terhadap Peningkatan Prestasi

Hasil Belajar Siswa MTsN Malang I, RS. PI, 2004

The Liang Gie, Cara Belajar Yang Efisien, Pusat Kemajuan Studi UMG Press, Yogjakarta,1975

William F. Glueck, Lawrence R. Jauch, Manajemen Strategis dan Kebijakan Perusahaan, Erlangga, Jakarta, $\mathrm{tt}$ Zuhairini dkk., Filsafat Pendidikan Islam, Bumi Aksara, Jakarta, 1989 